\title{
Rights Offering and Its Effect on Share Price Movement: A Study of Commercial Banks
}

\author{
Hari Prasad Pathak, PhD* \\ Sweta Gupta**
}

Received on 25 August 2018; Revised on 30 November 2018; Accepted on 10 December 2018

\begin{abstract}
This paper examines the effect of rights share issue on share price movement in the banking sector covering the period 2007/08 to 2016/17. In order to find out the share price movement in different selected points of time, pre and post right issue and price relatives were calculated considering the price of 90 days before the right announcement date as the beginning index. Five different points of time were selected to observe the share price movements assuming the announcement date as the reference point of time. Stock price data were obtained from the website of NEPSE. The paper uses correlation coefficient to examine whether the overall market movement has any relationship with the individual share price change. Coefficient of determination is used to identify what proportion of the variation in the share price is explained by the event of right share issue. The result shows that right offering announcements have the signaling effect, but it is negative. The share price of Nepalese commercial banks decreases after the announcement of right in spite of the increase in the market index in the corresponding period. The results highlight the information asymmetry behavior which induces a negative change in share price after the rights announcements. The implication of the result is that investors can anticipate the nature of change in share price after rights issue announcements and develop strategic plans to improve the trading activity.
\end{abstract}

Keywords: Commercial banks, right announcement, rights issue, stock return.

\section{INTRODUCTION}

The history of Nepalese capital market began with the flotation of common equity share by Biratnagar Jute Mills Ltd. in 1937 A.D. The introduction of Company Act in 1964 had opened the door for the companies to go public. The activities under financial capital market of Nepal were unsystematic until Securities Exchange Centre Ltd. was established in 1976 A.D. In the process of developing the Nepalese securities market, Security Board of Nepal (SEBON) was established in 1993 A.D. as an apex body with the objective to regulate, promote and protect the Nepalese capital markets. The then Government converted Securities Exchange Centre Ltd. into Nepal Stock Exchange under the governance and regulation of SEBON in 1994 A.D. that has made the financial trading floor more systematic and organized.

Nepalese capital market is dominated by the banking and financial institutions as other sectors

*Dr. Pathak is Associate Professor in Faculty of Management, Prithvi Narayan Campus, TU, Pokhara.

** Ms. Gupta is freelance researcher.

Corresponding author: Dr Hari Prasad Pathak.E-mail: haripathak75@gmail.com 
are comparatively inactive and silent regarding the issuance of different securities like equity shares, debentures, right shares, and other financial instruments. Right share issue is one of the attractive alternatives for the banking sectors for raising additional funds required to them. It is the privilege given to the existing shareholders to retain their control position proportionately equal in the management of the company. The practice of rights issuance in Nepal was initiated in 1995 A.D. by Nepal Finance and Saving Corporation.

Right share is an option-based financing approach where existing shareholders are given the right, but not the obligation, to purchase the proportionate number of shares that is equal to the fraction of their current holding (Holderness \& Pontiff, 2016). This fractional purchase helps to maintain the original ownership percentage of the shareholders. Usually, rights are the negotiable instrument which is transferable. It has the feature of transferability and negotiability because some shareholders may not have sufficient money to exercise their rights. Some may like to sell some part and exercise the remaining part of the right issue. Similarly, some shareholders may have an adequate fund for the purchase, but they may not consider the right issue as a profitable option comparative to other options available. In such a case, they have the right to transfer their rights. While on the other instances, somebody may have the money to subscribe the offering, but may not have the sufficient rights to subscribe. Hence, they are given an opportunity to subscribe the right share through the provision of transferring the right. To provide incentives for shareholders to participate, a rights offering is typically priced at a substantial discount to the exchange price (Holderness \& Pontiff, 2016).

The changes in corporate financial policies affect stock prices in systematic and predictable ways. However, the economic rationale for this market reaction has not been entirely resolved. A major part of theoretical explanations relies on asymmetric information, signaling theory, market efficiency, liquidity hypothesis and cash substitution hypothesis. (Malhotra, Thenmozhi, \& Gopalaswamy, 2012, p. 11)

Positive stock price movements are observed in the case of seasoned equity issue (Barns \& Walker, 2006; Kang \& Stulz, 1996). However, the long run reaction to seasoned capital issues is reported to be mostly negative in the United States (Allen \& Soucik, 2008; Bayless \& Jay, 2003). But, in the Asian countries the reaction to seasoned capital issues is observed to be positive (Barns \& Walker, 2006; Kang \& Stulz, 1996). Nevertheless, there is evidence of no significant impact of the seasoned equity issue announcement on the firm's operating performance according to a study by Dubois and Jeanneret (2000) in Switzerland.

According to Malhotra, Thenmozhi and Gopalaswamy, (2012) the reasons why markets respond differently to announcements of seasoned equity offerings are: (i) different issuing methods; (ii) information effects; (iii) the economic conditions under which a firm raises additional external equity; (iv) institutional differences; and (v) industry effects. Hence, it is a matter of interest to know how stock price reacts in response to the right issue announcement in Nepal. In this paper, an attempt has been made to examine the recent trend of right issue practices in Nepal and the focus is to analyze the effect of right issues on stock price movement. The paper also attempts to identify the proportion of right shares amount in total public issues amount.

This paper is organized as follows. Section 2 explains the literature review. Section 3 presents the data and methodology used in the study, while section 4 explains the right share issue practices in commercial banks, the contribution of right issue on total public issue and the share price movement in response to the right share announcement. Section 5 concludes and brings out the implications of the study. 


\section{LITERATURE REVIEW}

Equity share, preference share and debt instruments are the major sources of financing a corporate firm. Rights issue is one of the instruments to raise additional capital by increasing existing equity shares (Pathak \& Giri, 2008). There should be certain procedural steps for the company to issue right share to the existing shareholders. Company Act 2006 has mentioned that public companies can issue right share according to the provision mentioned in this act. Based on this act and the directives and guidelines of regulatory authorities like NRB and SEBON, Nepalese banks issue the right share to their existing shareholders. In case the right issue is undersubscribed, the banks call for the tender to the public for selling the unsold rights. In the context of Nepal, if a shareholder does not want to exercise the right to buy additional shares then he/she can transfer the right to another person. Alternatively, investors can just let the rights issue lapse. Rights are, however, non tradable on the open market in Nepal.

Empirical evidence has shown mixed results regarding the impact of right share issues on the share price movement. Hansen (1988) found that the underwritten right offerings are associated with a price decline of more than four percent just prior to the sale. This is contrasting to the public offering where there is little price concession. He argues that this price dip is due to the transaction costs for placing new securities. For an underwritten right offering, transaction costs that include flotation cost and price concession are higher than public offerings. So, he suggests, it is not surprising that companies prefer public offerings than right offerings.

In their study, Pathak and Giri (2008) found mixed results regarding the impact of right offerings on share price movement of Nepalese companies. The general market prices of the majority of the companies were decreased after the announcement of right share. The result of the study contrasts with the theory, which says that the share price increases after the right announcement and decreases after the issue of right share.

Lukose and Rao (2003) and Heron and Lie. (2004) stated management issue new shares only when the market overvalues the shares. They showed record of firms that have superior stock price performance prior to the announcement of equity offerings. This finding is similar to the finding of Thenmozhi, Malhotra, and Gopalaswamy (2007), who concluded that the share price should not fall if the firm issues safe debt (default and risk free) to finance investment. This is because, based on the assumption that managers act on behalf of existing shareholders, rational investors presume that managers issue new shares only when they believe the stock is overvalued. In contrast to the above, Holderness and Pontiff (2013), stated that, if the major reason for issuing shares is to take advantage of overvalued equity, this would explain the rather limited use of rights offerings. Modigliani and Miller (1958) showed that in the absence of information asymmetries and taxes, the manner in which firms finance their investments is irrelevant. They also found that when managers believe that the capital market undervalues the firm's equity, the optimal financing choice is to issue risk- free debt or use a pre-emptive stock issue. Paudel (2015) found that rights share was the major source of capital increment for the listed companies in Nepal and the right share of commercial banks covered maximum portion in total right issuance. Finance companies and development banks ranked the second and third position regarding the coverage in the total rights issuance. About 96 percent of the total rights issue of listed companies was subscribed.

Holderness and Pontiff (2016) in a more recent paper found on average only 64 percent of the existing shareholders participated in valuable domestic rights offerings in the U.S. They noted that the stock market reacts more negatively to the larger wealth transfers. Their findings suggest that agency 
conflicts influence the use of rights offers. Bist (2017) examined the empirical relationship between stock market development and economic growth in Nepal over a period of 22 years from 1993 to 2014. Findings of this study indicate that market capitalization has a positive impact on economic growth both in the long as well as in the short run. The result showed that inflation has a negative and significant impact on GDP per capita in the long as well as in the short run.

Several literature deals with the effect of seasoned capital issue announcements on stock price movement. These past literature reveal that there are mix results regarding the stock price reaction to the seasoned capital issue announcements. Recent and complete knowledge on how Nepalese stock market reacts to such announcements is still lacking. This study fills up this gap and draws a link between right share issue announcements and stock price movement in Nepalese capital market.

\section{DATA AND METHODS}

The study covers a period of ten years starting from the fiscal year 2007/08 to 2016/17. In order to show the practice of rights issuance in Nepal, authors have taken the data of all the rights issuing companies during the study period. The number of these firms varies from year to year as many firms were merged with each other and some were acquired by other firms during the study period. But, to calculate the effect of right issue on share price movement, only five commercial banks have been taken as a sample. The sample banks are - Laxmi Bank, Sunrise Bank, Sanima Bank, Nepal SBI Bank and Agricultural Development Bank. The banks included in the sample qualify the criteria that they remained listed on the Nepal Stock Exchange (NEPSE) during the fiscal years 2007/08 to 2016/017, performed operations and issued right shares during this time period, and submitted annual reports to NEPSE and Nepal Rastra Bank. Data on right issues were obtained from the annual reports of the sample banks, Security Board of Nepal, Nepal Rastra Bank and NEPSE. Stock price data were collected from the website of NEPSE.

In order to find out the share price movement in different selected points of time, before and after the right issue, price relatives were calculated considering the price of 90 days before the right announcement date as the beginning index. The five different points of time were selected to observe the share price movements assuming the announcement date as the reference point of time. The selected times are: (i) Ninety days before the announcement date (base date); (ii) Seven days before the announcement date; (iii) The day of the announcement; (iv) Seven days after the announcement date; (v) Ninety days after the announcement date. Correlation coefficient between the individual share price and market price has been computed to examine the relationship between them. In order to find out, what proportion of the variation in the share price is explained by the market factor and what proportion is explained by the event of right share issue, coefficient of determination is calculated.

This study has used banking sub-index as a proxy of market returns instead of NEPSE overall index. This is because, if NEPSE overall index is used, that may not represent the true market returns of commercial bank sector as the NEPSE overall index is the composite index of different sectors like banking, insurance, hydro, manufacturing, hotel, trading etc. So, it is believed that taking banking subindex as a benchmark would represent the true market price of the banking sector. 


\section{RESULTS AND DISCUSSION}

\subsection{Contribution of Right Issue on Total Public Issue}

Right share is the most popular alternative to raise the additional capital required for the corporate firms in Nepal. It covers a major proportion of the total public issues. Table 1 shows the contribution of the rights issues in the total public issues during the study period. It is observed that the trend of right issue in Nepal is highly fluctuating in the last decade. It ranges from Rs. 452 million to Rs. 45,642 million. On average, 63 percent of the total public issue amount is covered by the right issue amount. In terms of the number of issues, 60 percent is the right issue. Fiscal year 2016/017 marks the highest amount as well as the number of right issues. The contribution of right issue amount in FY 2016/017 on the total public issue is 77 percent. It is the highest contribution during the study period. Fiscal years 2011/012 and 2012/013 observed a very less number of right issues. It is also observed that the lowest contribution of right share issue amount on the total public issue amount during ten years was in the FY 2011/012.

Table 1

Contribution of Right Share Issue on Total Public Issue

(Rs. in millions)

\begin{tabular}{ccccccc}
\hline FY & $\begin{array}{c}\text { Public issue } \\
\text { amount } \\
\text { (Rs) }(\mathrm{A})\end{array}$ & $\begin{array}{c}\text { Right issue } \\
\text { amount } \\
(\mathrm{Rs})(\mathrm{B})\end{array}$ & $\begin{array}{c}\text { B as \% } \\
\text { of A }\end{array}$ & $\begin{array}{c}\text { No. of public } \\
\text { issue (C) }\end{array}$ & $\begin{array}{c}\text { No. of right } \\
\text { issue (D) }\end{array}$ & D as \% of C \\
\hline $2007 / 08$ & 11,896 & 7,606 & 64 & 72 & 49 & 68 \\
$2008 / 09$ & 14,875 & 11,615 & 78 & 63 & 50 & 79 \\
$2009 / 010$ & 14,107 & 10,963 & 78 & 72 & 35 & 49 \\
$2010 / 011$ & 7,078 & 5,049 & 71 & 48 & 31 & 65 \\
$2011 / 012$ & 2,950 & 452 & 15 & 25 & 7 & 28 \\
$2012 / 013$ & 10,602 & 3,939 & 37 & 35 & 5 & 14 \\
$2013 / 014$ & 7,267 & 4,243 & 58 & 46 & 26 & 57 \\
$2014 / 015$ & 14,435 & 2,308 & 16 & 48 & 22 & 46 \\
$2015 / 016$ & 18,999 & 9,404 & 50 & 55 & 37 & 67 \\
$2016 / 017$ & 59,395 & 45,642 & 77 & 101 & 76 & 75 \\
\hline
\end{tabular}

a Total public issue amount includes IPO, FPO, right share, debenture and mutual funds.

\subsection{Sector-wise Right Issue in Listed Companies}

Public companies must list their securities in NEPSE within the 45 days of securities allotment. Before, the listed companies in NEPSE were divided into eight sectors or sub-indices. But, recently the insurance sector has been divided into life insurance and non-life insurance sectors. Likewise, development bank sector has been split as development bank sector and micro finance sectors. Thus the number of sectors has reached ten. However, this study has used the previous classification, and thus, has eight sub-indices in the analysis. Table 2 presents the status of the rights share issue in each sector during the last decade. 
Table 2

Sector-wise Right Issue in Listed Companies

(Rs. in millions)

\begin{tabular}{lcccc}
\hline \multirow{2}{*}{ Sectors } & \multicolumn{2}{c}{ Right issue } & \multicolumn{2}{c}{ Right issue } \\
\cline { 2 - 5 } & Number & Percentage & Amount (Rs) & Percentage \\
\hline Commercial bank & 55 & 16 & 52,492 & 52 \\
Development bank & 141 & 42 & 22,734 & 22 \\
Finance company & 105 & 31 & 17,524 & 17 \\
Insurance Company & 32 & 9 & 5,579 & 6 \\
Hydropower & 5 & 1 & 2,892 & 3 \\
Manufacturing and & 0 & 0 & 0 & 0 \\
Processing company & & & 0 & 0 \\
Hotels & 0 & 0 & 0 & 0 \\
Others & 0 & 0 & 101,221 & 100 \\
\hline Total & 338 & 100 & & 0 \\
\hline
\end{tabular}

Source: Annual reports of NEPSE \& SEBON

The listed companies in Nepal have issued right shares 338 times during the study period. In terms of the number of right issues, development banks are in the front, making 42 percent of the total number of issues in the country. However, in terms of the amount, commercial banks share the largest portion, making 52 percent of the total right share issues amount of corporate sectors. It is seen that, though commercial banks comparatively have a smaller number of right issue cases than development banks and finance companies, they covered the largest portion of right issue amount among all sectors in Nepal. Surprisingly, no right issues were made by the manufacturing and processing companies, hotels and other sectors during the study period. It is found that bank and financial institutions in Nepal have occupied 97 percent of the total right offerings.

\subsection{Instrument-wise Security Issue}

Table 3 presents the structure of security issue in Nepal from the fiscal year 2007/08 to 2016/017. Nepalese corporate firms are found collecting required capital mainly through the initial public offering, further public offering, rights offering and debenture issues. However, initial public offering and right share are the two major instruments preferred by the firms to collect the required funds. This is the reason why ordinary share and right share together covers the major proportion (87\%) of the total public issue. The total public flotation amounted to Rs. 161,604 million during the study period of ten years in which the contributions of right shares were nearly 63 percent. Ordinary share issue holds the second position while debenture and mutual funds issues take the third and the fourth position respectively.

\subsection{Right Share Issue Practices in Commercial Banks}

In the fiscal year 1997/98, Nepal Bank Limited issued rights share amounting to Rs. 241.95 million and become the first commercial bank to issue right share in Nepal. After that Everest Bank issued the right share of Rs. 119 million in the fiscal year 2000/01. There are 55 cases of right issues by the commercial banks in the study period of ten-year. (See Table 2 and Appendix). In this period, commercial 
Table 3

Structure of Security Issue During Fiscal Year 2007/08 to 2016/017

\begin{tabular}{|c|c|c|c|}
\hline S.N. & Instruments & $\begin{array}{l}\text { Public issue amount } \\
\text { (Rs in millions) }\end{array}$ & Percentage of the total public issue \\
\hline 1 & Right share & 101,221 & 62.64 \\
\hline 2 & Ordinary share & 39,783 & 24.62 \\
\hline 3 & Debenture & 13,100 & 8.10 \\
\hline \multirow[t]{2}{*}{4} & Mutual funds & 7,500 & 4.64 \\
\hline & Total & 161,604 & 100.00 \\
\hline
\end{tabular}

banks have issued rights amounting to Rs. 52,492 million. Till last year, many commercial banks were in the process of mergers or acquisitions in order to reach their capital requirements as per requirement of Nepal Rastra Bank. Beside acquisitions and mergers, right share issues have become the most preferable alternative for commercial banks to raise the required additional capital.

During the study period, 25 commercial banks issued the right shares while seven did not. Later on, Lumbini Bank was merged with Bank of Kathmandu. Bank of Asia and NIC Banks merged with each other. DCBL which had changed its name as Grand Bank was merged with Prabhu Bank. Commerz and Trust Bank Nepal (which had not issued right share) was acquired by Global IME Bank. This merger and acquisition process reduced four commercial banks in the market. Therefore, the total number of commercial banks was confined to 28 after the merger. Seven commercial banks which did not issue the rights share during the study period are - Rastriya Banijya Bank, Nabil Bank, Civil Bank, Standard Chartered Bank, Nepal Credit and Commerce Bank, Commerz and Trust Bank Nepal (acquired by Global IME Bank) and Bank of Kathmandu.

There were total of 55 cases of right issues by 25 commercial banks during the study period (See Appendix). Before starting the joint operation by Lumbini Bank and BOK, the right share amount of Rs. 250 million and Rs. 300 million was issued by Lumbini Bank in the FY 2007/08 and 2008/09 respectively. However, BOK has not issued any rights to its shareholders. Similarly, right issue amounts of NIC Bank and Bank of Asia are shown separately in the table in Appendix before they were merged; and for Prabhu Bank and DCBL also, the figures before the merger are presented separately.

Nepal Bank issued the rights twice only but covers the highest percentage of total rights issue $(9.84 \%)$. Similarly, Laxmi Bank and Nepal Bangladesh Bank hold the second and third position in issuing the right share as they occupy the 8.54 percent and 8.24 percent respectively. On the contrary, Lumbini Bank, DCBL (renamed as Grand Bank Nepal) and Global IME Bank were the banks issuing the lowest amount of rights, each has issued approximately one percent of the total issue amount. Sunrise Bank issued right share the highest number of times during the period of ten years. Laxmi Bank, Siddhartha Bank, Machhapuchchhre Bank and Bank of Asia hold the second position in terms of the number of right issues. The practice of right share issue by the commercial banks of Nepal shows inconsistency. Some banks have issued comparatively a very high amount of rights while some have issued a very low amount of rights. 


\subsection{Analysis of Share Price Movement}

This section analyses the right share issue and its impact on the share price movements of the listed commercial banks. Besides, the signaling effect of the issue of the right shares, the price of the share

Table 4

Share Price Movement of Sample Commercial Banks

\begin{tabular}{|c|c|c|c|c|c|c|}
\hline \multicolumn{4}{|c|}{ Individual share price } & \multicolumn{3}{|c|}{ Market index } \\
\hline $\begin{array}{l}\text { Selected } \\
\text { points of time }\end{array}$ & $\begin{array}{c}\text { Share price } \\
\text { (Rs) }\end{array}$ & $\begin{array}{c}\text { Index } \\
\text { (price relative) }\end{array}$ & $\begin{array}{l}\% \text { Change from } \\
\text { base value of } 100\end{array}$ & $\begin{array}{l}\text { Market } \\
\text { index }\end{array}$ & $\begin{array}{l}\text { New } \\
\text { index }\end{array}$ & $\begin{array}{l}\% \text { Change from } \\
\text { base value of } 100\end{array}$ \\
\hline \multicolumn{7}{|c|}{ Panel A: Share price movement of Laxmi Bank } \\
\hline I & 529 & 100 & - & 848 & 100 & - \\
\hline II & 477 & 90 & $-10 \%$ & 736 & 87 & $-13 \%$ \\
\hline III & 461 & 87 & $-13 \%$ & 714 & 84 & $-16 \%$ \\
\hline IV & 438 & 83 & $-17 \%$ & 810 & 95 & $-6 \%$ \\
\hline $\mathrm{V}$ & 470 & 89 & $-11 \%$ & 1,122 & 132 & $32 \%$ \\
\hline \multicolumn{7}{|c|}{ Panel B: Share price movement of Sunrise Bank } \\
\hline I & 377 & 100 & - & 777 & 100 & - \\
\hline II & 420 & 111 & $11 \%$ & 876 & 113 & $13 \%$ \\
\hline III & 425 & 113 & $13 \%$ & 866 & 112 & $12 \%$ \\
\hline IV & 406 & 108 & $8 \%$ & 859 & 111 & $11 \%$ \\
\hline $\mathrm{V}$ & 362 & 96 & $-4 \%$ & 809 & 104 & $4 \%$ \\
\hline \multicolumn{7}{|c|}{ Panel C: Share price movement of Sanima Bank } \\
\hline I & 741 & 100 & - & 1,181 & 100 & - \\
\hline II & 914 & 123 & $23 \%$ & 1,447 & 123 & $23 \%$ \\
\hline III & 929 & 125 & $25 \%$ & 1,405 & 119 & $19 \%$ \\
\hline IV & 684 & 92 & $-8 \%$ & 1,419 & 120 & $20 \%$ \\
\hline $\mathrm{V}$ & 800 & 108 & $8 \%$ & 1,713 & 145 & $45 \%$ \\
\hline \multicolumn{7}{|c|}{ Panel D: Share price movement of NSBI Bank } \\
\hline $\mathrm{I}$ & 1,433 & 100 & - & 1,313 & 100 & - \\
\hline II & 1,450 & 101 & $1 \%$ & 1,526 & 116 & $16 \%$ \\
\hline III & 1,460 & 102 & $2 \%$ & 1,516 & 116 & $16 \%$ \\
\hline IV & 1,062 & 74 & $-26 \%$ & 1,501 & 114 & $14 \%$ \\
\hline $\mathrm{V}$ & 940 & 66 & $-34 \%$ & 1,439 & 110 & $10 \%$ \\
\hline \multicolumn{7}{|c|}{ Panel E: Share price movement of Agricultural Development Bank } \\
\hline $\mathrm{I}$ & 761 & 100 & - & 1,554 & 100 & - \\
\hline II & 670 & 88 & $-12 \%$ & 1,673 & 108 & $8 \%$ \\
\hline III & 683 & 90 & $-10 \%$ & 1,735 & 112 & $12 \%$ \\
\hline IV & 683 & 90 & $-10 \%$ & 1,720 & 111 & $11 \%$ \\
\hline $\mathrm{V}$ & 528 & 69 & $-31 \%$ & 1,387 & 89 & $11 \%$ \\
\hline
\end{tabular}

Source: Website of NEPSE

Note. $\mathrm{I}=90$ days before the announcement date (base date); II = 7 days before the announcement date; III = The day of announcement; IV $=7$ days after the announcement date; $\mathrm{V}=90$ days after the announcement date. 
fluctuates due to many other causes. Therefore, considering the announcement date as the base time, five different periods of time (as discussed in methodology section) were taken in order to eliminate the influence of general market movement and to obtain a clear result. A series of five values of prices for these five different periods of time for each bank are extracted to examine the changes in share price at these different points of time, before and after the rights announcement. Before the 90 days of the announcement it is supposed that there are not any rumors about the right issue by the company. So, there may not be any effects of right issue on share price. Similarly, after 90 days the effect of right issue would be settled down.

Table 4 shows the share price movement of sample banks before and after the rights issue along with the movement of market index simultaneously. The price relative shown in the third column is calculated by either adding the percent increase in the price or subtracting the percent decrease in the price of the share from 100 base value. Here, the base value 100 is considered as beginning index value which is established for the price 90 days before the right announcement date. Percentage change in the price, in the column four, is calculated by differentiating the announcement date price from price of the share on each relative point of time and dividing it by the price on 90 days before the announcement. The same method is followed for the calculation of values for market index in columns six and seven.

According to the theory, the share price increases after the right share announcement date until the book close date. Second columns of each panel corresponding to the row IV in Table 4 shows that the actual share price has fallen after the seven days of the announcement for all the sample banks. On the other hand, the market index was increased after the seven days of the announcements of Laxmi Bank and Sanima Bank. Instead of increasing the price relative of Laxmi Bank was decreased by 17 percent seven days after the right announcement, whereas market index was decreased by only six percent during the same time. This decline in share price of Laxmi Bank was not consistent with the decline in the overall market after the announcement. Hence, it can be concluded that the signaling effect of rights offering was more responsible for the change (decline) in share price of the bank than the change in overall market movement. The cases of rest of the sample banks were also similar. For instance, the individual price relative of Sanima, NSBI, and ADB (as shown in the fourth column corresponding to row IV of respective banks) have decreased after the seven days of right announcement, while that of market index has increased during the same period. The price relative of Sunrise Bank has increased during this period, but this increase is less than that of the market price increase.

Coming to the 90 days after the announcement of right share issue, price relative of Laxmi Bank, Sunrise Bank and NSBI Bank, have decreased whereas market index has increased during the same period. The cases of Sanima and ADB are also not different; in response to the 45 percent increase in the market index (market price relative), there is only 8 percent increase in the price relative of Sanima Bank and in response to the 11 percent decrease in the market index (market price relative), there is a huge decrease of 31 percent in the price relative of ADB. As the price movements of these banks were not consistent with the price movement of overall market index, it could be inferred that the signaling effect of rights offering was more responsible for these inconsistence change in the share price of the company. The finding is consistent with the finding of Paudel (2015) who also found that the market price of share is influenced by right offerings. 


\subsection{Relationship Between Individual Share Price and Market Index}

After the issue closed date, the share of the companies is traded at ex-right price. In the actual market, right share issue is not the only factor to bring fluctuation in the price, but general market movement largely affects the share price of the companies. So, the correlation between share price of individual bank and market index is calculated in order to see the relationship between individual share price and market index. Coefficient of determination is calculated to find what percentage of other factors brings variation in share price beside the announcement of issue of right shares. Here, share price of sample banks is considered as dependent variable and banking sub-index as independent variable.

Table 5

Relationship Between Individual Share Price and Market Index

\begin{tabular}{lcc}
\hline Commercial banks & $\begin{array}{c}\text { Correlation coefficient } \\
\text { with market returns }(\mathrm{r})\end{array}$ & $\begin{array}{c}\text { Coefficient of } \\
\text { determination }\left(\mathrm{R}^{2}\right) \text { in \% }\end{array}$ \\
\hline Laxmi Bank & 0.077 & 0.60 \\
Sunrise Bank & 0.88 & 77.44 \\
Sanima Bank & 0.18 & 3.24 \\
Nepal SBI Bank & -0.035 & 0.12 \\
Agricultural Development Bank & 0.604 & 36.48 \\
\hline
\end{tabular}

Source: Website of NEPSE

As mentioned in the methodology section, banking sub-index is taken as the proxy of the market index. Table 5 reports there is a great difference among banks in the observed correlation coefficients between the share price of individual sample banks and the market index. In case of Laxmi Bank, there is a very low degree of a positive correlation coefficient $(\mathrm{r}=.077)$ between share price and market index. The coefficient of determination of Laxmi Bank indicates that only 0.60 percent of the variation in the share price is explained by market factor and rest are by the event of right share issue. Hence, it can be concluded that right share issue has more impact on share price movement of Laxmi Bank than overall market factors. The correlation coefficient of share price of Sanima Bank and Nepal SBI Bank with a market index is very low. Moreover, lower value of the coefficient of determination of these banks indicates that the variation in the share price of these banks are less explained by market factor and highly explained by the event of right share issue. Hence, it can be concluded that right share issue has more impact on share price movement of Laxmi bank, Sanima Bank and Nepal SBI Bank than overall market factors. However, the case of Sunrise Bank is different. A very high correlation coefficient and coefficient of determination of Sunrise bank indicates that right issue event has less impact on its share price.

\section{CONCLUSION}

Right share issuing practice is rapidly growing in Nepal especially in the banking and financial institutions. However, the history of right offering by Nepalese corporate sector is not long. It was started only 23 years ago by Nepal Finance and Saving Corporation. Right share issues amount covered 63 
percent of the total public flotation in the last decade. Banking and financial institutions are more active than the other sectors in this matter. Commercial banks occupy the first position among all the corporate sectors in terms of the volume of right shares issue. Bank and financial institutions of Nepal occupy 97 percent of the total right offerings. Manufacturing and processing companies, hotels and trading sectors have not issued any right share during the last ten years.

Initial public offering and right share are the two major means preferred by Nepalese firms to collect the required capital. The right offering announcement has the signaling effect on the share price of the commercial banks. However, the right announcement gives a negative signal to the stock market. The finding is consistent with the result of Paudel's (2015) study, who found that the market price of share is influenced by right offerings. The share price of Nepalese commercial banks decreases after the announcement of right in spite of the increase in the market index in the corresponding period. This is not consistent with the theory of right offering. However, the finding is consistent with the result of the earlier study by Pathak and Giri (2008). The anomaly in the share price movement after the right announcement may be either because of an inefficient market or leak of information before it becomes formally public. Therefore, future study can be carried out to identify the cause of the anomaly by testing the efficiency of the Nepalese capital market.

This study is an attempt to establish a link between seasoned capital issue announcements and stock price movement. This link is important because it is documented that the rights issue announcement affects share price negatively and it conveys there is an anomaly in the market. The results highlight the information asymmetry behavior which induces a negative change in share price after the rights announcements, and there is evidence of reducing share price after the right announcement. Investors can anticipate the nature of change in share price after rights issue announcements and develop strategic plans to improve the trading activity.

\section{ACKNOWLEDGEMENTS}

We thank Devi Lal Sharma, Resam Lal Poudel, Jas Bahadur Gurung, and two anonymous referees for their helpful comments and suggestions.

\section{REFERENCES}

Allen, D. E., \& Soucik, V. (2008). Long run underperformance of seasoned equity offerings: Fact or an Illusion? Mathematics and Computers in Simulation, 78(2), 146-154. doi:10.1016/j.matcom.2008.01.034

Barns, E., \& Walker, M. (2006). The seasoned-equity issues of UK Firms: Market reaction and issuance method choice. Journal of Business Finance and Accounting, 33(1), 45-78.

Bayless, M., \& Jay, N. R. (2003). Is the performance of firms following seasoned equity issues anomalous. Journal of Banking and Finance, 27(7), 1273-1296.

Bist, J. P. (2017). Stock market development and economic growth in Nepal: An ARDL representation. Journal of Finance and Economics, 5(4), 164-170. doi: 10.12691/jfe-5-4-2

Dubois, M., \& Jeanneret, P. (2000). The long-run performance of seasoned equity offerings with rights: Evidence from the Swiss market. Retrieved from http://ssrn.com/abstract=239873

Hansen, R. S. (1988). The demise of the rights issue. Review of Financial Studies, 1(3), 289-309. doi: 10.1093/ $\mathrm{rfs} / 1.3 .289$ 
Heron, R. A., \& Lie, E. (2004). A Comparison of the motivations for and the information content of different types of equity offerings. The Journal of Business, 77(3), 605-632.

Holderness, C. G., \& Pontiff, J. (2016). Shareholder nonparticipation in valuable right offerings: New findings for an old puzzle. Journal of Financial Economics, 120(2), 252-268. Retrieved from https:/www2.bc.edu/ clifford-holderness/Rights_Offerings_and_Shareholder_Nonparticipation.pdf

Holderness, C. G., \& Pontiff, J. (2013). Shareholder nonparticipation in valuable rights offerings. doi: 10.2139/ Ssrn. 2173543

Kang, J. K., \& Stulz, R. M. (1996). How different is Japanese corporate finance? An investigation of the information content of new equity issues. Review of Financial Studies, 9, 109-139.

Lukose, P. J. J., \& Rao, S. N. (2003). Operating performance of the firms issuing equity through rights offer. Vikalpa, 28(4), 25-40.

Malhotra, M., Thenmozhi, M., \& Gopalaswamy, A. K. (2012). Evidence on changes in stock price and liquidity around rights issue announcement: Industry specific analysis. International Journal of Business Insights and Transformation, 5(2), 11-28.

Modigliani, F., \& Miller, M. H. (1958). The cost of capital, corporation finance and the theory of investment. The American Economic Review, 48(3), 261-297.

Pathak, H., \& Giri, D. (2008). Right share issue practices in Nepal. The Journal of Nepalese Business Studies, 5(1), 93-100.

Paudel, R. K. (2015). Analysis of right share practice in Nepal and its effect in market price (Unpublished master's thesis). Faculty of Management, Prithvi Narayan Campus, Pokhara, Nepal.

Thenmozhi, M., Malhotra, M., \& Gopalaswamy, A. K. (2007). Announcement effect of rights issue on stock returns: A study of selected Indian manufacturing companies. Journal of Services Research, 7(1), 215-231.

\section{Appendix}

\section{Rights Issue by Individual Commercial Banks}

(Rs. in millions)

\begin{tabular}{llccc}
\hline S.N. & Name of Bank & $\begin{array}{c}\text { Right issue } \\
\text { cases (number) }\end{array}$ & $\begin{array}{c}\text { Right issue } \\
\text { amount (Rs.) }\end{array}$ & $\begin{array}{c}\text { \% of Right issue } \\
\text { amount }\end{array}$ \\
\hline 1 & Nepal Investment Bank & 2 & 1,004 & 1.91 \\
2 & Kumari Bank & 3 & 1,708 & 3.25 \\
3 & Laxmi Bank & 4 & 4,483 & 8.54 \\
4 & Siddhartha Bank & 4 & 2,473 & 4.71 \\
5 & Machhapuchchhre Bank & 4 & 3,772 & 7.19 \\
6 & Nepal Bangladesh Bank & 2 & 4,326 & 8.24 \\
7 & NMB Bank & 2 & 678 & 1.29 \\
8 & Citizens International Bank & 3 & 4,070 & 7.75 \\
9 & Sunrise Bank & 5 & 2,994 & 5.70 \\
10 & Global IME Bank & 1 & 500 & 0.95 \\
11 & Nepal SBI Bank & 2 & 2,429 & 4.63 \\
12 & Prime Commercial Bank & 2 & 2,335 & 4.45 \\
13 & Nepal Bank & 2 & 5,163 & 9.84 \\
14 & Century Bank & 3 & 3,268 & 6.23 \\
12 & N & & &
\end{tabular}


Appendix (Continued)

(Rs. in millions)

\begin{tabular}{|c|c|c|c|c|}
\hline S.N. & Name of Bank & $\begin{array}{c}\text { Right issue } \\
\text { cases (number) }\end{array}$ & $\begin{array}{l}\text { Right issue } \\
\text { amount (Rs.) }\end{array}$ & $\begin{array}{c}\% \text { of Right issue } \\
\text { amount }\end{array}$ \\
\hline 15 & Prabhu Bank & 1 & 642 & 2.28 \\
\hline 16 & Sanima Bank & 2 & 3,122 & 5.95 \\
\hline 17 & MEGA Bank & 1 & 810 & 1.54 \\
\hline 18 & Agricultural Dev Bank & 1 & 1,969 & 3.75 \\
\hline 19 & Himalayan Bank & 1 & 643 & 1.22 \\
\hline 20 & Janata Bank & 1 & 1,030 & 1.96 \\
\hline 21 & Everest Bank & 1 & 1,509 & 2.87 \\
\hline 22 & $\begin{array}{l}\text { NIC Bank (becomes NIC Asia Bank after } \\
\text { merger) }\end{array}$ & 1 & 158 & 0.30 \\
\hline 23 & $\begin{array}{l}\text { Lumbini Bank (merged with Bank of } \\
\text { Kathmandu) }\end{array}$ & 1 & 550 & 1.05 \\
\hline 24 & $\begin{array}{l}\text { DCBL (renamed as Grand Bank Nepal; lat- } \\
\text { er merged with Prabhu Bank) }\end{array}$ & 1 & 554 & 1.05 \\
\hline 25 & $\begin{array}{l}\text { Bank of Asia (merged with NIC Bank and } \\
\text { became NIC Asia Bank after merger) }\end{array}$ & 4 & 2,302 & 4.38 \\
\hline & Total & 55 & 52,492 & 100 \\
\hline
\end{tabular}

